\title{
NOVAS FRONTEIRAS TEÓRICAS PARA A RESPONSABILIDADE SOCIAL EMPRESARIAL: O PAPEL DAS EMPRESAS NO DESENVOLVIMENTO SUSTENTÁVEL DOS TERRITÓRIOS
}

\author{
Raquel Oliveira Wildhagen \\ Mestre em Administração pela Pontifícia Universidade Católica de Minas Gerais - PUC/MG \\ quelwildhagen@gmail.com
}

Armindo dos Santos de Sousa Teodósio

Doutor em Administração de Empresas pela Fundação Getúlio Vargas - FGV/SP

Professor da Pontifícia Universidade Católica de Minas Gerais - PUC/MG armindo.teodosio@gmail.com

\author{
Yasmine Santos Mansur \\ Doutoranda em Administração pela Pontifícia Universidade Católica de Minas Gerais - PUC/MG \\ yasmine.mansur@gmail.com
}

\section{Jorge Andrés Polanco de Mesa}

Doutor em Socio-economía del desarrollo - Escuela de Altos Estudios en Ciencias Sociales de París Professor da Universidad de Medellin - UDEM

japolanco@udem.edu.com

\begin{abstract}
RESUMO
Este artigo de natureza teórica tem como principal objetivo contribuir para a construção de novos marcos teóricos, em bases críticas, sobre a responsabilidade das empresas no desenvolvimento sustentável dos territórios. Para isso, apresenta-se, em um primeiro momento, as abordagens da Nova Sociologia Econômica como uma via para se pensar o desenvolvimento para além da perspectiva econômica somente. Em um segundo momento, discutem-se as contradições dos conceitos de desenvolvimento sustentável e as implicações de sua institucionalização. Em seguida, são problematizadas algumas abordagens da Responsabilidade Social Empresarial com foco em uma discussão crítica sobre a Teoria dos Stakeholders, muito presente nos estudos tradicionais sobre o papel das empresas no desenvolvimento sustentável de territórios.
\end{abstract}

Palavras-chave: Desenvolvimento sustentável; Nova sociologia econômica; Responsabilidade social empresarial; Territórios.

\section{NEW THEORETICAL FRONTIERS FOR CORPORATE SOCIAL RESPONSIBILITY: THE CORPORATE ROLE IN SUSTAINABLE DEVELOPMENT OF TERRITORIES} \begin{abstract}
This paper aims to contribute to the construction of new theoretical frameworks in critical bases on corporate responsibility in the sustainable development of territories. For this, we present at first the approaches of New Economic Sociology as a way to reflect about the development beyond the pure economic perspective. In a second step, we discuss the contradictions of sustainable development concepts and the implications of its institutionalization. Then we investigate some approaches on corporate social responsibility with focus on a critical discussion on the Theory of Stakeholders which is a very present theory in traditional studies on the role of business in sustainable development of territories.
\end{abstract}

Keywords: Corporate social responsibility; New economic sociology; Sustainable development; Territory. 


\section{INTRODUÇÃO}

O debate sobre sustentabilidade vem se ampliando cada vez mais no contexto global, impulsionado por uma série de fatores que têm levado uma parcela da sociedade a repensar os padrões de desenvolvimento atualmente adotados. Entretanto, essa discussão incita muitos debates, visto que, não raras vezes, os países chamados do "Sul" reivindicam o direito ao crescimento econômico, tendo como espelho os países do "Norte", e justificam seu atraso econômico pelos séculos de colonialismo outrora sofrido. Esse discurso, entretanto, pode levar a um outro tipo de colonialismo, esse muito mais sutil, que provocaria uma integração e homogeneização forçada, orientada para as oportunidades do mercado mundial (Sachs, 1988; Layrargues,1998; Leff, 2009).

Em momentos de debate sobre os rumos do desenvolvimento, é comum ainda se manifestarem posições que têm como pressupostos a oposição entre crescimento econômico e proteção ambiental e/ou a ideia de que o avanço das atividades econômicas, metrificadas pelo produto interno bruto (PIB), por si só seriam capazes de gerar soluções para outros campos da vida em sociedade, chamado "efeito transbordamento", ou seja, do crescimento econômico surgiriam melhorias para a equidade e justiça social, a ampliação das liberdades democráticas e até mesmo para a proteção continuada do meio ambiente. Pensar no desenvolvimento de forma sustentável implica em buscar novos caminhos em meio às compreensões dicotômicas sobre o desenvolvimento.

A sustentabilidade, porém, se cerca de contradições, tornando-se, por vezes, um jargão vazio de sentido, abrindo espaços para diversos grupos da sociedade a utilizarem da maneira como bem entenderem, da forma que melhor lhes convir, visando interesses diversos (Sen, 2000; Jacobi, 2005; Veiga, 2009; Gonçalves-Dias \& Teodósio, 2011). Acompanhada de uma polissemia de significados, atribuições e usos, a sustentabilidade sofre com o fato de que atores sociais imaginam que a conservação ambiental necessariamente restringiria o desenvolvimento ou que desenvolvimento necessariamente significaria poluição ambiental (Lelé, 1991). Na mesma linha, Baroni (1992) argumenta que há na literatura uma revisão crítica sobre o tema, sendo, muitas vezes, os termos desenvolvimento sustentável, ecossocioeconomia e sustentabilidade usados com o mesmo sentido, embora tenham significados distintos. De toda forma, as diversas noções acerca da sustentabilidade destacam a necessidade do envolvimento de diferentes atores ligados às esferas social, ambiental, cultural, política e econômica em torno de uma proposta de transformação efetiva do território. Questões culturais, históricas e as relações afetivas, que se estabeleceriam no e com o território, deveriam ser consideradas como pautas no debate (Zhouri, Laschefski \& Pereira 2005; Acselrad \& Bezerra, 2009; Leff, 2009).

Sob outra perspectiva, emerge do lado empresarial um discurso cada vez mais voltado para a Responsabilidade Social Empresarial (RSE). Para além de demonizações e santificações das ações empresariais, que surgem nos muitos debates sobre o tema, percebe-se que a temática socioambiental constitui hoje um ponto central na agenda de qualquer organização empresarial por diferentes motivos, que vão desde a pressão de organizações da sociedade civil (OSCs), o avanço da legislação ambiental e até mesmo a decisão empresarial de procurar ser protagonista na adoção de tecnologias ambientais. Ao se revisar a literatura sobre a RSE, é possível perceber dois caminhos sendo traçados: um que vai no sentido das discussões clássicas de Freeman (1984), incorporando o sentido da ética nos negócios, aprimorando e relegitimando as empresas como atores centrais na sustentabilidade. Outro, que caminha na linha dos estudos críticos sobre RSE, discutindo suas fragilidades e rupturas, questionando o papel das empresas na sustentabilidade dos territórios em que atuam e se tal sustentabilidade seria possível mantendo os padrões de produção, consumo e desenvolvimento atuais (Weiss, 1995; Greenwood, 2007; Abramovay, 2009; Gond, Kang, Moon, 2011; Gonçalves-Dias \& Teodósio, 2011; Banerjee, 2012; Dentchev, Haezendonck, van Balen, 2015; Sheehy, 2015). O que se constata é que a própria crítica aos atores empresariais acaba por não considerá-los como mais um dos atores do território, mas sim como "o ator" do território, ou seja, aquele que tudo pode, consegue e detém. Isso acaba por resultar em uma contradição analítica 
quando se assume que nos territórios existem distintos atores com distintas capacidades de incidência nas dinâmicas de sustentabilidade.

Para a construção da fundamentação teórica dessa pesquisa, buscou-se nas teorias da Nova Sociologia Econômica as conexões que poderiam, de fato, correlacionar os estudos de RSE com a sustentabilidade dos territórios, uma vez que apontam para a importância da dimensão sociológica e se contrapõem a uma visão eminentemente utilitarista, tecnicista e economicista dos fenômenos econômicos e/ou relativos aos atores de mercado, que, muitas vezes está presente, inclusive nos estudos do campo da Administração que tratam de temas considerados politicamente, socialmente e ambiental corretos, como a Responsabilidade Social Empresarial e a Gestão Ambiental. (Abramovay, 2004; Serva \& Andion, 2006; Levèsque, 2007).

\section{INSTITUCIONALIZAÇÃO DO DESENVOLVIMENTO SUSTENTÁVEL}

O termo DS vem sendo cada vez mais incorporado aos discursos organizacionais. Um dos passos decisivos para que a noção de DS viesse a se institucionalizar foi o lançamento do relatório "Nosso futuro comum" ou, simplesmente, "Relatório Brundstland", visto que foi elaborado em 1983 pela Comissão Mundial sobre Desenvolvimento e Meio Ambiente (Comissão Mundial sobre Meio Ambiente e Desenvolvimento, 1988), da Organização das Nações Unidas (ONU), sob a presidência da então primeira-ministra norueguesa, Gro Harlem Brundstland. Apesar de amplamente conhecida, cabe aqui retomar a definição sobre DS contida no relatório: "[...]aquele que atende às necessidades do presente sem comprometer a possibilidade de as gerações futuras atenderem as suas próprias necessidades" (Cmmad, 1988, p. 46). Sem querer negar a relevância do relatório e o papel da institucionalização da noção de DS na difusão e promoção de percepções e práticas mais avançadas na proteção ao meio ambiente, bem como a centralidade desse conceito nos tempos atuais, é fundamental aprofundar a compreensão sobre quais controvérsias, críticas e debates desperta.

Os apontamentos desse Relatório, porém, esbarram em um grande paradoxo conforme aponta Layarargues (1998). Para o Relatório "Nosso Futuro Comum", "há sempre o risco de que o crescimento econômico prejudique o meio ambiente, uma vez que ele aumenta a pressão sobre os recursos ambientais" (Cmmd, 1991, p.44). O DS, portanto, tem limites, não limites absolutos, mas impostos pelo atual estágio da tecnologia e da organização social ante os recursos ambientais e a capacidade da biosfera de absorver os efeitos das atividades humanas (Layrargues, 1998). Essa tecnologia e organização social podem ser aprimoradas e geridas, porém, no sentido de um novo crescimento econômico. Dessa forma, a Cmmd aponta que a pobreza generalizada não seria mais fato inevitável, sendo que no contexto do DS, ela passaria a não ser apenas um mal em si, pois "[...]num mundo onde a pobreza e a injustiça são endêmicas, sempre poderão ocorrer crises ecológicas e de outros tipos" (CMMD, 1991, p.47). O relatório atesta que a pobreza é um dos principais problemas ambientais do mundo, afirmando que seria inútil abordar esses problemas sem uma perspectiva global das desigualdades do mundo (Lélé, 1991).

Tal ideia sugere uma circularidade como uma retroalimentação positiva, isto é, quanto mais pobre, maior pobreza haverá. Ocorre a partir daí uma intensa propaganda em torno do círculo vicioso da pobreza, com o propósito de justificar a necessidade da continuidade do crescimento econômico, e omitir o peso da responsabilidade ambiental do consumo excessivo do Norte, a poluição da riqueza (Layrargues, 1997, p.6).

Essa forma de entendimento apontada pela Cmmd frisa que o crescimento econômico pode continuar no mesmo ritmo, desde que novas tecnologias não poluentes sejam incorporadas nas atividades industriais. No entanto, mesmo que as tecnologias se adequem ao contexto, será que as mudanças sociais e culturais acompanhariam essas transformações, uma vez que uma das características da sociedade industrial de consumo é justamente o desperdício? (Layarargues, 1997). Sem essa mudança os recursos naturais continuarão sendo tencionados e as novas tecnologias terão um impacto muito voltado à diminuição das emissões de poluentes, mas os recursos naturais

Revista de Gestão Social e Ambiental - RGSA, São Paulo, v. 9, n. 3, p. 3-23, set./dez., 2015. 
Novas fronteiras teóricas para a responsabilidade social empresarial: o papel das empresas no desenvolvimento sustentável dos territórios

continuarão correndo o risco da escassez. O paradoxo da circularidade se encontra exatamente nesse ponto: o Relatório aponta que há sempre o risco de o crescimento econômico degradar o meio ambiente, mas seria a pobreza, porém, o fator de maior contribuição para essa degradação, e como solução dever-se-ia agir em prol da diminuição da pobreza, por meio do crescimento econômico.

Além disso, Lélé (1991) afirma que muitos dos conceitos disseminados sobre DS, são, na verdade, abordagens conceituais da sustentabilidade ecológica e/ou social. Portanto, Lélé (1991) e Veiga (2009) acreditam ser o DS, nada além do que um "[...]desenvolvimento que pode ser continuado", e esse desenvolvimento pode ser medido, inclusive, pelo PIB e não necessariamente pela incorporação das questões ambientais. Diante do amplo "leque" que o conceito de DS apresenta, Sachs (2007) argumenta que apesar de o DS ser uma alternativa média entre o economicismo arrogante e o fundamentalismo ecológico, ele deveria ser socialmente receptivo e implementado por métodos favoráveis ao meio ambiente, por meio de uma distribuição diferente da propriedade e da renda e requerendo algum tipo de intervenção e planejamento por parte do Estado, além de estratégias complementares entre o Norte e o Sul. Assim, lamenta que "[...]a revolução ambiental tenha coincidido com a contra-revolução neoliberal e o ressurgimento do mito do laissezfaire"(Sachs, 2007, p. 63), o que o levou a justificar a necessidade de uma ecosocioeconomia.

Esse termo surgiu na década de 1970 com a obra do economista e ambientalista Karl William Kapp e foi incorporada à discussão do ecodesenvolvimento que também ganhava fôlego na década de 1970 em que um dos percussores foi justamente Ignacy Sachs. A proposta da ecosocioeconomia seria a de trazer para o debate do DS questões relacionadas a um desenvolvimento mais integrado, combinando três pilares: eficiência econômica, justiça social e prudência ecológica (Sachs, 2007). Esses três pilares apresentados por Sachs (1988) levariam ao desenvolvimento mais equitativo dos países subdesenvolvidos, uma vez que o critério econômico provocaria um rearranjo nas estruturas econômicas da sociedade ao integrar o meio ambiente como dimensão do desenvolvimento; o critério social buscaria mitigar as disparidades sociais, gerando maior equidade, justiça e valorização de comunidades locais; e o critério ambiental colocaria o meio ambiente em uma condição central nas discussões, análises e ações de desenvolvimento.

Essa noção teria como foco principal o crescimento endógeno, considerando os saberes locais. De acordo com essa perspectiva, para o Terceiro Mundo se desenvolver seria necessário que percorresse um caminho diferente daquele marcadamente industrial adotado pelo primeiro mundo (Layrargues, 1998; Sachs, 2007). "Deveria engajar-se na pesquisa de modelos de desenvolvimento endógenos, qualitativamente diferentes do norte-americano e europeu" (Layrargues,1998, p.135). Nessa perspectiva, o quadro cultural, antes ignorado tornava-se relevante, bem como os estilos de vida próprios de cada nação. O desenvolvimento passaria a não ser apenas pela ótica da economia, mas traria como tema central a criatividade cultural e morfogênese social (Cechin, 2010).

Outra discussão que a noção da ecosocioeconomia apresenta é sobre a perspectiva do chamado "teto de consumo" (Sachs, 2007), na qual o nível de consumo dos países do Norte é tido como insustentável. Tentar igualar o consumo dos países do Sul ao nível dos países do Norte levaria o planeta a um colapso, sendo ideal aumentar o consumo dos países do Terceiro Mundo ao passo que se diminui o consumo dos países de Primeiro Mundo até que se chegue ao ponto de equilíbrio da biosfera (Layrargues, 1997; Sachs, 2007).

A Cmmd visivelmente evita essa ótica, uma vez que aponta para o desenvolvimento de novas tecnologias que minimizariam os impactos ambientais e permitiriam erradicar a pobreza, levando os países a níveis menos desiguais de consumo, por meio do aumento do consumo e não na sua diminuição. Dessa forma, os países do Norte não seriam responsabilizados pela degradação ambiental, sendo que o problema com o qual o desenvolvimento sustentável teria que lidar seria apenas um: a "poluição da pobreza" (Layrargues, 1998). Fato é que o DS, em um primeiro momento, foi aceito tanto pelo Sul quanto pelo Norte, devido a diferentes fatores e interesses. Enquanto um, o Sul, buscava investimentos para mitigar a pobreza tão poluidora, o outro, o Norte, queria omitir a poluição da riqueza. O grande desafio, segundo Layrargues (1997) aparecerá quando 
chegar o momento em que o Sul terá que arcar com o ônus financeiro da recuperação ambiental no futuro, uma vez que aceitou que a poluição vem, única e exclusivamente, da pobreza, desonerando o Norte de suas responsabilidades pela geração de problemas ambientais.

Sachs (2007) acredita que a ecossocioeconomia é uma noção altamente operacional, exigindo para isso que as culturas e os ecossistemas sejam reconhecidos, problematizando as formas de produção local e seu relacionamento com o ambiente, de forma a compreender em maior complexidade os dilemas e problemas enfrentados por cada população nos territórios. Além disso, essa noção parte de um planejamento e da construção de estratégias dentro de um processo participativo, nos quais os cidadãos - detentores de maior saber local - possam participar dos processos de tomada de decisões (Layrargues,1998).

A ecosocioeconomia vai além das proposições de acelerar ou diminuir o ritmo do crescimento, significando alterar-se drasticamente os rumos da civilização. Considerando a transição do liberalismo para o neoliberalismo, na qual o Estado intervém cada vez menos e os mercados atuam de forma mais independente, a resposta para o aumento da competitividade e também para a solução dos problemas sociais e ambientais estaria concentrada no mercado, conforme postulam algumas abordagens sobre desenvolvimento sustentável. Já na noção da ecosocioeconomia, a solução para os desafios sociais e ambientais não residiria apenas no mercado e na ação das organizações empresariais, mas sim na ação conjunta e participativa que se daria a partir da articulação entre sociedade civil e Estado (Lélé, 1991; Layrargues, 1998; Levésque, 2007).

Outra noção que se faz presente nas discussões sobre meio ambiente e desenvolvimento e que foi adotada como referência para essa pesquisa, é a da sustentabilidade. Essa terminologia, com frequência, é confundida com o conceito de DS e ecossocioeconomia. A noção de sustentabilidade tem sua origem nas vertentes ambientalistas a partir de duas correntes: (1) conservacionista e preservacionista, difundida por filósofos, cientistas naturais e políticos no século XIX; e (2) interior da corrente tradicional, porém, a partir da década de 1960 passou por mutações polissêmicas com a politização do tema e dividiu-se em duas concepções: (1) gestão ambiental; e (2) ecologização do sistema social (Neder, 2002).

A primeira vertente, a do conservacionismo, vai de encontro das ideias iniciais sobre sustentabilidade das Ciências Biológicas, que a aplicam a recursos renováveis, principalmente aqueles que podem ser exauridos pela exploração descontrolada. A sustentabilidade para exploração desses recursos está na ideia de que só é possível uma exploração permanente se observados os ciclos naturais de renovação desses produtos (Barbieri, 2001; Neder, 2002). Para os recursos nãorenováveis, tais como combustíveis fósseis e exploração mineral, a sustentabilidade seria sempre uma questão de tempo, pois, obviamente, quanto mais racionados e menos desperdiçados esses recursos forem, mais tempo durarão (Barbieri, 2001; Neder, 2002).

A segunda vertente define sustentabilidade como um processo de "ecologizar" o sistema social, "[...]obtendo uma soma positiva do planejamento local e global em torno de processos produtivos sinérgicos ou afins aos ecossistemas" (Neder, 2002, p. 37). Nesse contexto, a sustentabilidade dialogaria muito fortemente com a ecossocioeconomia, sendo considerada por autores, tal como Neder (2002), como a mesma coisa. Essa vertente, assim como a ecossocioeconomia, exigiria uma alteração nos hábitos de consumo humano, se contrapondo aos argumentos a favor do caráter universalmente construtivo do crescimento econômico que defendem que o modelo produtivista tem como virtudes a geração de emprego e o incentivo à inovação (Veiga, 2009; Abramovay, 2012). Converge com a ideia de uma nova economia, em "[...]cujo centro estejam os limites da biosfera e a ética na tomada das decisões sobre o uso dos recursos (públicos, privados e associativos)" (Abramovay, 2012, p. 65)

A sustentabilidade implicaria em uma visão holística sobre os sistemas do planeta, buscando articular as dimensões social, econômica, ecológica, geográfica, e cultural simultaneamente nas discussões, análises e ações voltadas ao desenvolvimento. Para Sachs (1993), essas cinco dimensões representariam respectivamente: (1) a melhoria dos direitos e condições da vida humana, assim como, a diminuição da desigualdade social; (2) alocação e gestão eficiente de recursos, avaliada 
Novas fronteiras teóricas para a responsabilidade social empresarial: o papel das empresas no desenvolvimento sustentável dos territórios

mais pelos critérios macrossociais do que microempresariais e por fluxos regulares de investimento público e privado; (3) redução do consumo e da produção de resíduos, adoção de tecnologias limpas e regras claras que limitem a exploração de recursos naturais; (4) melhor distribuição dos espaços territoriais, principalmente em relação ao excesso de acumulação em áreas urbanas; (5) busca de concepções endógenas de desenvolvimento que respeitem as particularidades de cada ecossistema, de cada cultura e cada local.

Podemos considerar que, sendo o conceito de Sustentabilidade provindo da Biologia e da Ecologia, cuja lógica é circular e includente, representaria a tendência dos ecossistemas ao equilíbrio dinâmico, à cooperação e à coevolução, e responderia pelas interdependências de todos com todos, garantindo a inclusão de cada um. Diferentemente das definições de DS e Ecosocioeconomia, a sustentabilidade incorporaria em seu sentido o equilíbrio da natureza pela natureza, saindo do foco antropocêntrico presente nas outras abordagens.

O DS, entendido, literalmente, como o desenvolvimento que pode ser continuado, incorporou a discussão da sustentabilidade ecológica e o sentido integrador da ecossocioeconomia que apresenta uma proposta de mudança nas estruturas do desenvolvimento, por meio do pensar o desenvolvimento a partir do local para o global integrando as dimensões sociais, ambientais e econômicas. Entretanto, a interpretação que hoje dominaria o debate sobre DS, é a de que as formas tradicionais de desenvolvimento podem ser mantidas uma vez que haja uma mudança societal que englobaria os objetivos ou as restrições da sustentabilidade ecológica. Esses objetivos ecológicos, somados aos objetivos tradicionais, poderiam reforçar-se mutuamente. Lelé (1991), entretanto, questiona de que forma esses dois objetivos poderiam reforçar-se, uma vez que, no passado, se anulavam. Como não cair novamente em contradição? Colaborando para esse questionamento de Lélé (1991), Rattner (2010) contesta a incorporação da dimensão ambiental nos projetos de crescimento econômico, considerando-os insuficientes para a melhoria da qualidade de vida no planeta e, vai além, apontando para a necessidade de buscar-se padrões de consumo e de produção determinados socialmente para que, dessa forma, possamos avançar sobre a discussão de sustentabilidade fugindo dos padrões normativos. Dessa forma, tanto para Rattner (2010) quanto para Lélé (1991), sustentabilidade é uma perspectiva que é definida pelo consenso social. Assim, reconhecem que a discussão sobre sustentabilidade deve responder três questões: (1) O que tem que ser sustentado?; (2) Para quem?; e (3) Por quanto tempo?

\section{TERRITÓRIOS E SUSTENTABILIDADE}

A definição do que é território impulsiona uma discussão complexa sobre seus conceitos. Milton Santos, uma das principais referências dessa discussão, acredita que território é "[...]o lugar em que desembocam todas as ações, todas as paixões, todos os poderes, todas as forças, todas as fraquezas, isto é, onde a história do homem plenamente se realiza a partir das manifestações da sua existência" (Santos, 1999a). Para o autor, o território não pode ser entendido apenas pelo conjunto de sistemas naturais e de coisas superpostas, mas sim como território usado, ou seja, o chão mais a identidade, e identidade entendida como "[...]o sentimento de pertencer àquilo que nos pertence" (Santos, 1999a, p.8). O território, portanto, "[...]é o fundamento do trabalho, o lugar da residência, das trocas materiais e espirituais e do exercício da vida" (Santos, 1999a, p.8). Para Saquet (2011), é preciso compreender a dialética no e do território entre o concreto e o abstrato, superando o que é visível, o que está apenas no nível do concreto. Saquet (2011) afirma que a abstração é imprescindível para se compreender o território e, para isso, as formas e os conteúdos dos territórios precisam ser expressos no pensamento.

De acordo com Santos (1999b), a ciência política acabaria por ignorar o território, uma vez que o entenderia, na maioria das vezes, apenas a partir da divisão entre estados e municípios, mas não do conteúdo social nele inserido. Trata esse conteúdo de maneira quantitativa, medindo-o por meio de estatísticas, e excluí o dinamismo socioterritorial, que, segundo o autor, são formas-conteúdo relacionados à existência, fazendo com que o território deva ser visto sempre como algo em constante processo (Santos, 1999b). É o território que constitui o traço de união entre o passado e o futuro imediatos e deve ser visto como um campo de forças, como o lugar do exercício, de dialéticas e

Revista de Gestão Social e Ambiental - RGSA, São Paulo, v. 9, n. 3, p. 3-23, set./dez., 2015. 
contradições entre o vertical e o horizontal, entre o Estado e o mercado, entre o uso econômico e o uso social dos recursos (Santos 1999b). O território poderia ser entendido como uma construção social, a partir das diferentes formas de uso e apropriação do espaço geográfico (Saquet, 2011). Dessa forma, o território traz em si os contextos históricos e relacionais, formados a partir das relações de poder que ali se estabelecem, porém, envolvendo as redes de circulação e comunicação, a natureza exterior ao homem, as diferenças, as desigualdades e as identidades culturais (Saquet, 2011).

Em relação ao uso econômico do território, com a expansão cada vez maior das instalações das multinacionais e com o dinheiro circulando nos territórios este, cada vez mais, é global (Santos, 1999a). O autor levanta uma questão importante apontando que o dinheiro "[...]cria sua lei e a impõe aos outros, forçando mimetismos, adaptações, rendições, a partir de duas outras lógicas complementares: a das empresas e a dos governos mundiais" (Santos, 1999a, p.11). Dessa forma, a lógica do dinheiro das empresas seria a da competitividade, que faz com que qualquer empresa que busque o universo global aumente sua esfera de influência e de ação para se expandir, e isso transforma qualquer lugar, por mais insignificante que pareça ser, em uma peça fundamental no mundo da competitividade (Santos, 1999a). Para que essa lógica da competitividade empresarial funcione plenamente, é preciso apoiar-se nos governos mundiais, tais como o Fundo Monetário Internacional, Banco Mundial, bancos internacionais regionais, como o BID, pelo consenso de Washington, pelas Universidades centrais produtoras de ideias de globalização e pelas Universidades subalternas que aceitam reproduzi-las, já os Estados podem optar por atender os reclames da sociedade, uma vez que, as multinacionais escolhem lugares, em razão das respostas que imaginam poder ter e desertam esses lugares quando descobrem que já não podem mais oferecer tais respostas (Santos, 1999a).

O que estaria em jogo seria a ampliação do poder e a utilização cada vez maior do espaço da natureza socializada (Santos, 1999a). Essa relação entre a natureza e a sociedade poderia ser entendida como o suposto da produção do homem, que, por meio de suas ações sobre ela, acabaria por provocar alterações e modificações deste espaço e do próprio homem, refletindo na reprodução social e na construção da paisagem (Machado \& Saquet, 2011). A paisagem não seria, no entanto, algo estático, como um quadro que congela as externalidades sociais e da natureza (Machado e Saquet, 2011). Ela seria, em uma determinada porção do espaço, "[...]o resultado da combinação dinâmica, portanto, instável, de elementos físicos, biológicos e antrópicos que, reagindo dialeticamente uns sobre os outros, fazem da paisagem um conjunto único e indissociável, em perpétua evolução" (Bertrand, 1998, p.2). A paisagem deve ser entendida como a expressão concreta da relação entre sociedade e natureza, destacando-se as dimensões históricas e temporais, ou seja, a análise de suas transformações com base no tempo e na história (Bertrand, 1998; Machado \& Saquet, 2011).

Levando-se em consideração essa abordagem, a análise do território pode e deve ser somada às dinâmicas da paisagem, uma vez que esta serviria de instrumento de diálogo, com o qual, busca-se entender a diversidade e como as pessoas se organizam, constroem sua identidade e representam seu espaço (Machado \& Saquet, 2011). "Uma paisagem é uma escrita sobre a outra, é um conjunto de objetos que têm idades diferentes, é uma herança de muitos diferentes momentos" (Santos, 1999). O real do território e do desenvolvimento estariam em suas contradições e unidades dialógicas, fundindo-se entre as relações sociais, sociais-naturais, sociais-espirituais, em conflitos, contradições e interações, contendo em si heterogenias, mudanças, permanências, desigualdades, diferenças e identidades (Saquet, 2011).

Quando se pensa em território como demarcações geográficas que abrigam sistemas humanos e ecossistêmicos complexos, um jogo de oposições é evidenciado a partir de uma racionalidade imposta sobre as outras formas de ações e saberes ligados ao uso e a apropriação da natureza (Floriani, Ríos \& Floriani, 2013). Tal jogo conflitivo refletiria as formas como o modelo hegemônico de produção e consumo do espaço é planejado para ser, em sua ação individual, forçosamente indiferente ao seu entorno (Floriani, Ríos \& Floriani, 2013; Santos, 1999). Esse modelo ancora-se na visão hegemônica, tanto nas teorias de sociedade quanto nas ciências da natureza, da independência das populações em relação aos territórios, refletindo um processo político de construção social de espaço e tempo (Floriani, Ríos \& Floriani, 2013).

Não obstante, o território se oporia à plenitude dessa hegemonia: além das racionalidades típicas que atravessam o território, o espaço vivido admitiria a presença de outras racionalidades (e 
irracionalidades), em cujo âmago são priorizadas formas de convivência e regulação criadas a partir do próprio território, a despeito da vontade de unificação e homogeneização que caracterizam a racionalização econômico-instrumental do espaço (Floriani, Ríos \& Floriani, 2013). Ao se colocar os dispositivos da ação-cognição humana nessas bases, se abriria a possibilidade do não aprisionamento de antemão na rigidez de um esquema mental, que tende a impedir e reconhecer a ocorrência de emergências, de incertezas e de ambiguidades pela ação humana no interior dos processos sociais. Com isso, a própria criatividade desafiadora poderia operar a partir de um sistema de racionalidade aberto (Floriani, Ríos \& Floriani,, 2013).

A instauração de uma "imaginação espacial alternativa" permitiria pensar o espaço abertamente, como multiplicidades discretas, nos quais os elementos estão impregnados de temporalidades, isto é, como multiplicidades contemporâneas de outras trajetórias e vozes, cuja interpretação requer "[...]uma mentalidade aberta à subjetividade espacializada" (Massey, 2008, p. 93). Trata-se, portanto, de defender um modo de ser e pensar diferentes, a partir de uma imaginação e de uma atitude capazes de propiciar o desenvolvimento potencial de uma mentalidade aberta à subjetividade praticada, isto é, à vivência do espaço enquanto experiência de multiplicidades de coisas e de relações (Floriani, Ríos \& Floriani, 2013). Em outras palavras, a vivência do espaço deveria ocupar uma das posições de destaque no estudo da relação sociedade-natureza, a partir de um novo paradigma para pensar a sociedade-espaço: o paradigma da cultura, que negaria os antigos modelos, porque nenhum deles consegue dar conta dos sujeitos emergentes, cujas ações estariam centradas não apenas na política ou na sociedade, mas também na cultura (Floriani, Ríos \& Floriani, 2013). A cultura, interpretada pelo viés do espaço geográfico, não pode ser separada da ideia de território e paisagem, pois seria pela existência de uma cultura que se criaria um território. E é por ele que se exprimiria a relação simbólica existente entre a cultura e o espaço e identidade de um grupo social (Bonnemaison, 2002; Floriani, Ríos \& Floriani, 2013).

Nessa nova abordagem da geografia, os estudiosos reconhecem que as paisagens materiais não são neutras, mas refletiriam as relações de poder e as 'dominantes maneiras de ver' o mundo. Com isso, a paisagem passaria a ser entendida não apenas como resultado das interações materiais entre sociedade e meio ambiente, mas como consequência de uma maneira de olhar específica, passando a ser concebida como uma imagem cultural (McDowell, 1996; Floriani, , Ríos \& Floriani, 2013). De acordo com Floriani, Ríos \& Floriani, (2013), entre os homens e suas paisagens existiria efetivamente uma conivência secreta, em que o discurso racional científico, dissecador e classificador não pode dar conta. A paisagem seria, ao mesmo tempo, o seu prolongamento e o seu reflexo (Floriani, Ríos \& Floriani, 2013).

A partir daí, entramos em outro constructo desenvolvido fundamentalmente pelos estudos no campo da geografia: o topocídio. Este termo definiria a aniquilação deliberada dos lugares. Essa aniquilação decorreria de uma posição ideológica e cultural em relação ao ambiente que é transformado (Tuan, 1980). Se agora paisagens são entendidas como reflexos sociais e culturais dos homens, qual o real impacto de empreendimentos que alteram essa paisagem? Nessa visão dos estudos que recorrem à categoria do topocídio, os impactos iriam além da natureza, afetando a expressão mais clara de apego, cotidiano e sentimentos que explicam uma série de experiências pessoais e íntimas em determinado território (Tuan, 1980).

Esse fator, por si só, já seria um forte gerador de conflitos entre as empresas e a sociedade, somado à falta de transparência visto no tópico anterior, a não aceitação da implementação de empreendimentos que irão impactar as dinâmicas do território por grupos da sociedade, causariam um outro impasse, o que Acselrad e Bezerra (2009) denominam de "chantagem locacional" ou "chantagem de localização/deslocalização". As estratégias territoriais de capital dotadas de mobilidade potencial acrescida às empresas, aprisionaria parcelas importantes de populações locais na "alternativa" de promessa de emprego e renda, mesmo ao custo de submissão a riscos sociais e ambientais (Acselrad \& Bezerra, 2009). Esse aumento da mobilidade do capital seria, então, um dos "pivôs" dos conflitos ambientais locais por "[...]desregulação" nas áreas de chegada dos investimentos - denúncias e resistências à despossessão ambiental de populações locais, observada em áreas de expansão de fronteira capitalista, ou à imposição de riscos ambientais aos grupos sociais mais destituídos, em áreas de ocupação intensa" (Acselrad \& Bezerra, 2009, p. 3). 
Atores da resistência acabariam entrando em um embate, não apenas com as empresas geradoras dos conflitos, como também com parte da população interessada nos avanços que estes podem gerar a outros setores. Os portadores do poder, portanto, ganham uma força a mais, sendo que suas pressões podem se dar por meio de dois meios: (1) pela ameaça de retirada do investimento para outro local; ou (2) pela ameaça de que não se aceitando o empreendimento tal como a empresa o deseja, nenhuma outra atividade irá ali se implantar (Acselrad \& Bezerra, 2009). Com a imposição das condições mais acessíveis para si, os empreendimentos acabam tornando-se "“quase-sujeitos" das políticas de regulação dos territórios e "quase-sujeitos" dos limites de aceitabilidade dos riscos para a própria população local" (Acselrad \& Bezerra, 2009, p.4).

Em síntese, no processo da chantagem locacional, a população tenderia a submeter-se à essa manipulação por ter um poder de barganha restrito pelas condições econômico-sociais débeis em que vive, ficando, assim, cada vez mais sujeita aos riscos socioambientais dos empreendimentos. Estaria em vigor, segundo Acselrad \& Bezerra (2009), uma “[...]divisão socioespacial da degradação ambiental[...]" reduzindo o potencial socioprodutivo de várias comunidades e, consequentemente, seu bem-estar socioambiental. O próprio poder público estaria legitimando a atração locacional chantagista de investimentos, oferecendo uma série de benefícios, seja em recursos físicos ou fiscais, e estimulando inclusive uma "guerra predatória regional". A chegada desses empreendimentos não causa impactos apenas pela ação direta da sua produção, mas também pelas consequências das políticas ambientais que devem ser acionadas pelo poder público. É o caso das Unidades de Conservação. Os empreendimentos industriais, essencialmente, exigem uma contrapartida ambiental. No caso da mineração, por exemplo, exige-se que uma área, semelhante àquela a ser minerada, seja destinada para a conservação ambiental. Outras vezes, é o próprio estado e/ou os movimentos sociais que entram com o pedido de criação de parques ou unidades de conservação, muitas vezes para blindar a natureza da exploração industrial. Acontece que essas medidas para a conservação da natureza também impactam os povos tradicionais locais pois, usurpam os seus direitos à terra que seus antepassados viveram, o espaço coletivo no qual se realiza o seu modo de vida distinto dos centros industriais (Diegues, 1996). Essa usurpação se faz sob o discurso da necessidade de criação de espaços públicos e/ou de conservação em benefício da nação, quando na verdade é em benefício das populações urbano-industriais (Diegues, 1996).

Essas comunidades tradicionais rurais constroem uma representação simbólica sobre o espaço, sendo ali o meio em que desenvolvem sua agricultura de subsistência, o trabalho, as relações sociais, e a expulsão de suas terras implica a impossibilidade de continuar existindo como grupo, portador de uma cultura e de uma relação específica com a natureza (Diegues, 1996). O Estado, ao conduzir a criação desses espaços, age em favor dos interesses das sociedades industriais, criando espaços conflitantes entre as comunidades tradicionais, que antes o utilizavam para sua subsistência, e dos turistas, em grande parte pertencentes aos centros urbano-industriais, ou criando obrigatoriedades de Unidades de Conservação às empresas que, muitas vezes, se apropriam disso para construir seus discursos de RSE. $\mathrm{Na}$ verdade, o que está implícito é que as comunidades tradicionais rurais deveriam "sacrificar-se" em prol do "direito" das sociedades urbano-industriais em usufruírem de espaços naturais de lazer, em contato com a natureza (Diegues, 1996). Ou ainda, de criar áreas protegidas e com acesso restrito para se "preservar" a biodiversidade. E aqui encontra-se uma contradição, pois, ao exigir que empreendimentos altamente prejudiciais à biodiversidade mantenham Unidades de Conservação, além dos conflitos do empreendimento em si, sua contrapartida também gerará conflitos. Além do mais, a experiência tem mostrado que os proprietários individuais ou as empresas têm degradado os recursos naturais dentro de suas propriedades e que o próprio Estado tem criado políticas degradadoras do meio ambiente (Diegues, 1996).

\section{MERCADOS E SOCIEDADE NA NOVA SOCIOLOGIA ECONÔMICA}

A NSE ganhou fôlego a partir da década de 1980, tendo origem na sociologia econômica de Weber, Durkheim e Marx, voltando seu interesse para as bases deixadas pelos seus precursores, ou seja, os estudos dos fenômenos econômicos à luz de uma abordagem sociológica (Abramovay, 2004; Serva \& Andion, 2006; Levèsque, 2007). A sociologia econômica nessa década, por meio de suas diferentes correntes, passa então a se contrapor aos fundamentos da ciência econômica neoclássica, na tentativa de demonstrar que o mercado e os demais fenômenos econômicos são 
Novas fronteiras teóricas para a responsabilidade social empresarial: o papel das empresas no desenvolvimento sustentável dos territórios

construções sociais (Serva \& Andion, 2006). A NSE surge, então, com o intuito de combinar a análise dos interesses econômicos com a das relações sociais. Essa abordagem teórica rejeita a ideia de que o mercado e a sociedade são vistos como um só, em que a vida dos indivíduos se reduz a sua natureza econômica (Swedberg,2004; Abramovay,2009).

Os pressupostos e as noções que configuram as análises da NSE, entretanto, não se definem de maneira unânime, surgindo diversas vertentes no interior de seu campo epistemológico. Essa diversidade pode apresentar uma dicotomia: se, por um lado, se configura como um aspecto preocupante por gerar o risco de ruptura interna ou um novo "adormecimento", por outro, tal configuração atesta a riqueza do movimento, ensejando debates vigorosos, além de constituir uma rica fonte de energia para seu próprio avanço (Serva \& Andion, 2006).

Existem diversas correntes no âmbito da sociologia econômica, cada uma delas com seus conceitos centrais, suas opções de pesquisa, seus autores e obras-chaves. Entretanto, pode-se observar que tais correntes têm em comum o fato de realizarem uma crítica aos fundamentos da economia neoclássica e de partirem do pressuposto de que os fenômenos econômicos são essencialmente uma construção social. Swedberg (2004) descreve a sociologia econômica como o conjunto de teorias que se esforçam por explicar os fenômenos econômicos a partir de elementos sociológicos.

Levèsque (2007) aponta para algumas hipóteses que guiam as pesquisas no campo da NSE, destacando-se aquela relacionada à chamada "sociedade de risco", conforme a entende Ulrich Beck. $\mathrm{O}$ aumento dos riscos na vida social contemporânea poderia chegar ao ponto de que os atores sociais não hesitariam mais em falar dos riscos ambientais, o que poderia levar a se colocar assim a questão do desenvolvimento sustentável no centro das preocupações. O crescimento dos riscos revelaria os limites da racionalidade tecnocientífica e a necessidade de uma racionalidade social e ética, “[...]se quisermos que o futuro não seja moldado por cegos" (Levèsque, 2007, p. 50).

Incorporar as premissas da NSE nos permite ampliar o olhar sobre as dinâmicas entre atores da sociedade civil, no caso, Estado e mercado em torno das questões ambientais. Essa perspectiva teórica permite uma análise mais complexa das possibilidades, riscos, contradições e armadilhas da busca do desenvolvimento sustentável dos territórios. Além disso, reconhece o poder de diferentes atores, não apenas aqueles do mercado, nas interações das quais resultam os processos de sustentabilidade e insustentabilidade dos territórios. Um desses atores, cujo papel é muitas vezes menosprezado ou mitigado por estudos que não se fundamentam nas premissas da NSE, é o Estado (Levèsque, 2007).

Uma vez que a NSE se propõe a compreender a economia como uma totalidade social atores sociais e individuais - ela abre espaço para estudos que buscam repensar a economia no sentido do DS. Nesse sentido, o ambiente econômico não se reduz ao sentido mercantil, agregando tanto o não-mercantil quanto o não-monetário. Dessa forma, existe uma reafirmação da sociedade civil para novas regulações e novas formas de governança (Lèvesque,2007). A importância do contexto histórico coordena as interpretações e alerta para a necessidade de se observar a racionalidade dos atores - que se misturam com as crenças partilhadas e com as normas vigentes. Todas essas relações sociais influenciam as ações dos indivíduos. (Swedberg, 2004; Lèvesque, 2005)

É neste ponto que institucionalismo oferece uma contribuição fundamental para o estudo da governança, sobretudo em contextos nos quais o Estado, a sociedade e o mercado buscam estabelecer relações mais horizontais de interação. De acordo com Palier e Surel (2005), estas relações são produtos de ideologias, instituições e interesses. Por um lado, há os interesses associados com a lógica da ação e interação entre os atores, por outro, as instituições dizem respeito ao efeito cumulativo de decisões ou dispositivos que podem ou não ser um fator de dificuldade para a ação. Finalmente, as ideias remetem ao papel dos elementos cognitivos, que podem explicar as novas crenças que emolduram a ação. 


\section{RSE E DESENVOLVIMENTO DE TERRITÓRIOS}

Ao longo do tempo, as empresas foram transformando sua postura em relação às suas ações socioambientais. Nesse cenário de contestações, as empresas passaram a ser alvo de movimentos da sociedade civil que exerceram sob elas pressões, especialmente relacionadas à poluição, ao desemprego, consumo e as descriminações, entre outras (Kreitlon, 2004). E é nesse contexto que a conduta ética das empresas começa a ser debatida por um olhar mais crítico, em que se questiona sua responsabilidade para além de seus portões. O dogma segundo o qual as empresas devem consagrar-se exclusivamente à maximização de seus lucros começa a ser questionado por vários movimentos de contracultura (Kreitlon, 2004).

Esse processo não necessariamente resultou em avanços em termos da cidadania e da sustentabilidade, bem como não pôde ser percebido de forma homogênea em todos os lugares, pois cada campo organizacional possui dinâmicas e respostas diferentes aos desafios que enfrenta em cada território (Gonçalves-Dias, Teodósio \& Barbieri, 2007). No entanto, a regulação legal e pressão social, somadas ao desejo de melhoria da reputação organizacional e a diminuição dos riscos, diferenciação e busca por segmentos específicos de mercado e a internalização das questões socioambientais por conta das pressões externas, estariam impulsionando as organizações a um processo de mudança, ainda que permeado de contradições, idas e vindas e em uma velocidade muito aquém do necessário para a sustentabilidade (Gonçalves-Dias, Teodósio \& Barbieri, 2007).

O debate sobre a RSE, que tem incitado diversas abordagens conceituais que partem de campos e princípios distintos sobre os questionamentos éticos e sociais das empresas, muitas vezes adota elementos conceituais de variadas vertentes, não constituindo, portanto, em um campo de pesquisa, unificado e independente (Gonçalves-Dias \& Teodósio, 2011). Esse fato acaba promovendo críticas às teorias de RSE pelos adeptos à Teoria de Maximização de Riqueza, uma vez que as consideram conceitualmente frouxas e agregam muitos atores às dinâmicas empresariais sem explicar como os conflitos entre esses diferentes atores deveriam ser resolvidos, deixando o executivo sem qualquer princípio para tomada de decisões e avaliação de desempenho, valendo a lei das preferências pessoais (Silveira, Yoshinaga \& Borba, 2004). Essa argumentação tem fundamento na abordagem Neoclássica do economista Milton Friedman (1970) que, se baseando na teoria da "mão-invisível" de Adam Smith, argumenta que há uma e apenas uma RSE, voltada para a utilização dos recursos em atividades destinadas a aumentar seus lucros, contanto que permaneça dentro das regras do jogo, ou seja, se engaje na concorrência aberta e livre, sem enganos ou fraude (Falkenberg \& Brunsael, 2011). E as empresas envolvidas em atividades que não servem aos interesses dos seus acionistas, como projetos sociais, deveriam repassar os custos inerentes a isso aos clientes e, em última instância, à sociedade (Gonçalves-Dias \& Teodósio, 2011). Dessa forma, o mercado seria suficiente para promover o equilíbrio entre as empresas e a sociedade.

Friedman (1970) argumenta que a prática da RSE é antidemocrática, pois investe poder governamental em pessoas que não possuem mandato para governar, e é fútil tanto porque é improvável que o executivo seja capaz de antecipar as consequências sociais de suas ações, quanto porque impõe custos aos seus acionistas, clientes e/ou funcionários, o que provavelmente o faria perder apoio e, consequentemente, perder seu poder. Contrapondo-se à essa visão, Freeman (1984), argumenta que as atividades sociais não podem ser distinguidas de atividades econômicas, pois as atividades sociais teriam impacto direto sobre as atividades econômicas. Com base nesta perspectiva, o autor argumenta que as empresas não responderiam apenas aos acionistas, mas também aos funcionários, clientes, comunidades afetadas e a sociedade, sobre questões, tais como os direitos humanos, o bem-estar empregado e as alterações climáticas (Jenkins \& Yakvleva, 2006; Falkenberg \& Brunsael, 2011). Diferentemente do exposto por Friedman (1970) e pela abordagem neoclássica, Freeman (1984) acredita que a RSE seria uma ferramenta importante para se alavancar o desempenho econômico de uma empresa e, consequentemente, maximizar a riqueza dos acionistas. A instrumentalização da RSE, para esse autor, poderia melhorar a reputação da empresa, identificar oportunidades, testar novas tecnologias e produtos e, desta forma, adquirir vantagens competitivas no mercado globalizado (Porter \& Kramer, 2006; Shen \& Chang, 2009). 
A abordagem defendida por Freeman (1984), afirma que as empresas devem responder a suas partes interessadas, seus stakeholders. Mas como definir quem são esses stakeholders? São aqueles que têm uma relação estreita e "direito" à voz dentro das organizações? Ou engloba, amplamente interpretado, todos os grupos que podem afetar e serem afetados pela organização? Devem ser incluídos ativistas, concorrentes, o ambiente natural, a mídia? Como decidir? Para Phillips (2004), os stakeholders são, no mínimo, aqueles grupos com os quais a organização tenha voluntariamente aceito benefícios, e para quem a organização tem obrigações decorrentes de equidade, incluindo-se grupos, tais como financiadores, funcionários, clientes, fornecedores e comunidades locais. Freeman (1984) vai um pouco além e inclui em sua "lista" de stakeholders qualquer grupo ou indivíduo que pode ajudar ou prejudicar a empresa, apontando, além dos acima citados, os ambientalistas e o governo. Phillips (2004) destaca que os concorrentes podem certamente afetar uma organização e devem, portanto, ser considerados legítimos interessados, mas a organização e seus gestores não têm obrigação moral de comparecer ao seu bem-estar.

Tullberg (2005) apresenta uma abordagem que inclui um "teste de publicidade" em que a gestão é encorajada a considerar certas reações dos stakeholders em relação às atividades de RSE ou a falta delas. Uma organização pode gastar recursos na gestão de cobertura da mídia para o único propósito de fazer avançar os seus próprios objetivos, e não para uma questão de valor da mídia intrínseco (Phillips, 2004). No entanto, também pode optar por cuidar de certas questões, tal como o meio ambiente, por exemplo, porque seus stakeholders legítimos podem se preocupar profundamente com isso (Phillips, 2004). A Teoria dos Stakeholders (TS) pode ser indicada nos termos descritivos, instrumentais ou normativos, conforme Donaldson e Preston (1995) apontam. Por exemplo, Brenner e Cochran (1991) apontam para uma TS cujo objetivo seria descrever como as organizações operam para ajudar a prever o comportamento organizacional. Freeman (1984), por outro lado, utiliza a Teoria TS para desenvolver uma aproximação instrumental entre as práticas gerenciais, especialmente a estratégica. Donaldson e Preston (1995), no entanto, entendem a TS como essencialmente normativa. Para esses autores, ela não pode ser suportada apenas por motivos descritivos e instrumentais, mas ela vai além da simples ideia de que empresas possuem stakeholders e que os interesses desses devem ser considerados nas operações das organizações (Donaldson \& Preston, 1995). Ela pede uma análise sobre quais interesses as organizações devem atuar e a quem a administração serve. Enquanto a perspectiva geral da TS possa parecer plausível, Donaldson \& Preston (1995) acreditam haver rachaduras na base conceitual e empírica sobre a qual ela repousa. Estas falhas enfraquecem-na e mascaram algumas de suas implicações, subestimando a necessidade de uma mudança na sua estrutura fundamental se os interesses das partes interessadas se tornarem parte integrante das operações da empresa (Donaldson \& Preston, 1995).

Por causa das "rachaduras na fundação" da TS, uma série de questões podem ser levantadas sobre a utilidade e validade de quaisquer conclusões morais ou prescrições que oferece. Weiss (1995) afirma que a TS goza do status de paradigma no campo dos estudos organizacionais sobre responsabilidade social empresarial. Trata-se de um sistema geral de ideias e suposições, padrão, exemplos e afirmações estabelecidas. Apesar disso, o autor afirma que os fundamentos teóricoconceituais que estruturam a interpretação da postura e as ações empresariais baseados na noção de stakeholders permanecem pouco debatidos e criticados. $\mathrm{O}$ autor critica incisivamente as abordagens sobre stakeholders, visto que não colocariam em questão a natureza do capitalismo contemporâneo, tal como a expansão de grandes corporações globais detentoras de grandes capacidades e recursos concentrados. Além disso, essa perspectiva teórica assumiria também, assim como a concepção neoclássica sobre ação social dos atores econômicos, que princípios utilitaristas movem os grupos na luta por seus interesses, apesar de paradoxalmente negar o utilitarismo. Ao partir do princípio que as empresas e os mercados são formados por interesses voluntários, a TS justificaria o próprio comportamento autointeressado dos atores empresariais, apesar de afirmar pretender reprimi-lo e negá-lo (Weiss, 1995). 
Para que, de fato, a RSE ocorra na perspectiva dos stakeholders, Jones (1996) afirma que os gestores, ou seja, os tomadores de decisão nas empresas precisam desenvolver valores compatíveis e interesse em se responsabilizar pelos impactos causados pela organização. Além dessa dimensão individual, os níveis socioculturais e a racionalidade do setor empresarial e da própria empresa também precisariam avançar no sentido de dialogar com as partes envolvidas (Jones, 1996; Teodósio, 2008). Dessa forma, os projetos passariam a ser concebidos e desenvolvidos em conjunto com as comunidades, inclusive partilhando ações, custos e soluções a serem implementadas. "Nessa perspectiva, as comunidades e associações locais assumiriam status de parceiro privilegiado entre os stakeholders." (Teodósio, 2008, p. 79).

Para avançar nesse sentido, seria necessário também que se modificasse a concepção quanto à relação de aprendizagem entre empresa e comunidade. Anteriormente, tinha-se a ideia de que os indivíduos membros de comunidades desfavorecidas não poderiam sair de sua condição de excluídos. Isso faria, em tese, com que passivamente, aceitassem as intervenções tecnológicas e gerenciais promovidas pelas empresas nos territórios como a solução de problemas sociais e ambientais, segundo Teodósio (2008). No entanto, de acordo com o autor, os defensores de uma perspectiva modernizadora do investimento social de empresas afirmam que atualmente a relação com a comunidade pode ser extremamente frutífera para a empresa, visto que formas criativas, de baixo custo e mais adequadas às realidades sociais específicas podem surgir do contato entre gerentes e funcionários com indivíduos empreendedores, pertencentes às comunidades atendidas pelos projetos sociais. Assim, a aprendizagem tecnológica e gerencial se daria em via de mão dupla na relação entre organização e sociedade. (Teodósio, 2008).

Essa discussão, entretanto, gera alguns debates e controvérsias, tal como a assimilação dos saberes locais e tradicionais por grandes corporações sem as contrapartidas esperadas para comunidades, ampliando a dominância de relações de mercado para bens e esferas da vida, antes caracterizadas pela sua natureza pública e coletiva (Teodósio, 2008). Outra ideia, apontada por Teodósio (2008), é a de que os projetos não podem caracterizar-se pela extrema dependência de uma única fonte de financiamento externa, devendo caminhar para a autossustentação no médio e longo prazos. De acordo com Pereira (2001), esse ponto seria fundamental para romper com as práticas assistencialistas, pois partiria da ideia de investimentos alocados e multiplicados por meio do seu gerenciamento adequado.

Para Teodósio e Carvalho Neto (2003), no entanto, o questionamento mais relevante diz respeito à possibilidade de avanço da cidadania por meio do provimento de políticas públicas por agentes privados, cujos interesses e/ou resultado das ações voltar-se-iam para o aumento do comprometimento de seus trabalhadores com o trabalho e para a melhoria da imagem junto aos stakeholders, inclusive a comunidade no entorno de suas atividades, podendo resultar em maior dependência social do que emancipação. Ainda que as possibilidades de ganhos compartilhados entre comunidade e setor privado apontem cenários atrativos para os investimentos sociais de empresas, grande parte da literatura gerencial sobre stakeholders voltada ao tema distancia-se da ideia do conflito como estruturante das relações sociais, seja ele de natureza econômica, política, cultural, social ou de poder. (Teodósio \& Carvalho Neto, 2003).

Com isso, é possível afirmar que uma das motivações das empresas é a neutralização dos atores em conflito. Nesse sentido, as parcerias com OSCs representariam forte temor às empresas, pelo fato de que estas, ao descobrirem suas debilidades operacionais, poderiam levá-las a público (Teodósio, 2008). Em contrapartida, as OSCs correm o risco de terem seu nome, portanto, sua legitimidade e credibilidade, acessados pelas corporações por meio das parcerias para certificar práticas, produtos e serviços questionáveis do ponto de vista social e ambiental (Teodósio, 2008).

A literatura aponta para seis aspectos decisivos que deveriam ser considerados e operacionalizados para aprimoramento da performance das alianças entre empresas e organizações da sociedade civil: (1) identificação de projetos específicos para colaboração e dos recursos requeridos para o processo; (2) formulação de critérios para a seleção de parceiros; (3) desenvolvimento de procedimentos mutuamente aceitáveis para a colaboração; (4) definição clara e 
precisa de problemas e exploração de soluções viáveis; (5) focalização em tarefas de implementação rápida; (6) manutenção de confidencialidade por todas as partes (Rondinelli \& London, 2003; Meirelles, 2005).

Entretanto, esses aspectos podem reproduzir a visão de que os problemas sociais e ambientais se dariam de maneira pontual, podendo ser resolvidos por projetos específicos. "Além disso, situações de conflito são assumidas como indesejáveis e improdutivas, a menos que se manifestem dentro do fluxo de cooperação das parcerias" (Teodósio, 2008, p. 83). De acordo com Teodósio (2008), essa visão pode acabar reforçando a ideia de uma sociedade voltada apenas para as micromudanças, subtendendo que caberia ao Estado ou a outras organizações da sociedade civil o combate a fenômenos estruturais que levam aos problemas sociais e ambientais. As parcerias, nesse modelo, se dariam com a presença do Estado e as OSCs assumidas apenas fornecedoras de soluções para os problemas empresariais, podendo se transformar em instituições especializadas em bens concretos, perdendo o foco das lutas sociais mais amplas, muitas vezes marcadas pelo conflito entre sociedade civil e empresas. Além disso, as comunidades permaneceriam marginalizadas nesse processo. (Teodósio, 2008).

Vasconcellos, Alves e Pesqueux (2012) apontam para duas perspectivas analíticas sobre a TS a partir das ideias de Habermas. A primeira perspectiva, baseada em trabalhos desse pensador alemão anteriores sobre esfera pública (Habermas, 1984) e ação comunicativa (Habermas, 1987a, 1987b), trataria da avaliação ético-normativa da racionalidade das decisões administrativas por uma racionalidade comunicativa, com base no envolvimento dos stakeholders em debates travados em condições não distorcidas de "discurso ideal" (Habermas, 1987a, 1987b, 1984). Outra delas busca compreender as ações de responsabilidade social das empresas em contextos de criação de espaços deliberativos e de globalização, nos quais, apesar de ainda ser dominante a visão econômica por influência da TS, muitas empresas passaram a agir em diversas áreas antes exclusivas ao poder público.

Costa (2002) classifica três esferas para as quais as empresas privadas destinariam seus investimentos sociais: (1) os esforços estariam voltados para o público interno da organização, sendo característica deste tipo de investimento a melhoria das condições de trabalho, estrutura salarial, alimentação fornecida e benefícios aos empregados, dentre outros fatores; (2) a organização privada destinaria recursos e ações para o público localizado no entorno de suas atividades, como, por exemplo, a manutenção de áreas de esporte e lazer, escolas e outras instalações de provisão de políticas sociais, com restrições maiores ou menores quanto ao público beneficiário; e (3) os recursos e ações seriam focalizados na luta por direitos sociais, independentemente do público-alvo estar ou não ligado diretamente à empresa ou às comunidades nas quais opera. Costa (2002) afirma que esse último seria o nível ideal e desejável para as políticas, estratégias e/ou ações de responsabilidade socioambiental das empresas. No entanto, o autor afirma que grande parte das empresas brasileiras se encontra na esfera 2, preocupando-se com o entorno geográfico de suas plantas industriais.

Autores, tal como Windsor (2001), argumentam que esses discursos são representados e construídos baseando-se nos interesses corporativos e não nos interesses da sociedade. Para Abramovay (2009), porém, afirmar que as empresas só tomam estas iniciativas por interesse, apenas para consolidar sua posição competitiva por razões egoístas e não por uma preocupação socioambiental legítima implica em um ponto de vista ilusório, parcial e incapaz de compreender a complexidade que envolve a difusão de práticas de responsabilidade socioambiental do setor privado. É claro que o setor privado age por interesse. A questão consistiria em saber de que maneira se formam e se exprimem estes interesses. A principal crítica que se pode fazer aos que rejeitam, em princípio, o conceito de responsabilidade socioambiental empresarial é que tratam os interesses empresariais como se fossem imunes à pressão social. Tudo se passa como se os mercados, de fato, fossem mecanismos de equilíbrio, neutros, impessoais e situados, por assim dizer, acima da vida social. (Abramovay, 2009).

Para Abramovay (2009), a responsabilidade socioambiental refere-se, antes de tudo, a uma inversão na perspectiva que dominou a formação e o desenvolvimento das ciências sociais desde o 
século XVIII. É um convite para que se examinem não apenas os impactos do mercado na sociedade, mas, ao contrário, a maneira como a sociedade, que só poderia ser compreendida de forma organicamente articulada aos ecossistemas com que interage, produz e transforma os mercados (Abramovay, 2009). A ideia de que os mercados são mecanismos de equilíbrio, neutros e impessoais, dão lugar a uma nova visão: a de que os mercados não são autônomos em relação ao conjunto da vida social e não podem ser encarados como engrenagem de vidas permanentes. "Quando se abre a caixapreta dos mercados, o que há dentro é a sociedade[...]" (Abramovay, 2009, p.2) com seus conflitos e divergências.

A partir dessa perspectiva, o que se observaria é o mercado influenciando o meio ambiente e a sociedade e a sociedade e o meio ambiente influenciando o mercado. Nesse sentido, o sucesso empresarial não poderia ser analisado em separado da dinâmica de legitimação ou deslegitimação social das atividades, atitudes, ações, dos produtos, serviços, impactos e desdobramentos que as empresas geram nos territórios (Abramovay, 2009, Gonçalves-Dias \& Teodósio, 2011). De acordo com Acselrad (2000), é difícil não perceber que o debate sobre sustentabilidade tem se pautado predominantemente pelo recurso a categorizações socialmente vazias. Para o autor, as noções evocadas costumam não contemplar a diversidade social e as contradições que perpassam a sociedade quando está em jogo a legitimidade de diferentes modalidades de apropriação dos recursos territorializados. Essas abordagens embasam muitas discussões sobre a sustentabilidade, porém, cabe destacar que a abordagem baseada na teoria dos stakekholders considera as empresas como atores centrais responsáveis pela sustentabilidade. Desconsidera o fato de que sustentabilidade não é adjetivo de organizações e sim atributo dos territórios, e territórios não teriam stakeholders, ao contrário, apresentam atores em constante interação e ação em seu interior, ora convergindo, ora divergindo em torno de interesses, valores, motivações e posturas.

É improvável que qualquer revisão radical sobre a RSE vá emergir das organizações empresariais, dado que, como o discurso, é construída em níveis mais elevados da economia política. Para que qualquer revisão radical ocorra, seria necessária uma abordagem mais crítica no campo da teoria das organizações. Novas questões precisariam ser levantadas, não só sobre a sustentabilidade ecológica e social das corporações de negócios, mas da economia política em si. Seria preciso abrir novos espaços e oferecer novos quadros para diálogos entre organizações empresariais e os demais atores sociais, bem como analisar criticamente as dinâmicas das relações entre empresas, OSCs governos e sociedade civil. (Banerjee, 2012).

A RSE não poderia ser avaliada apenas por critérios econômicos. A ética ambiental, por sua vez, não poderia ser desenvolvida por meio de uma moralidade "eticamente pragmática de gestão", que atende, via de regra, principalmente, os interesses organizacionais (Fineman, 1998). Enquanto OSCs servem como contrapontos importantes às corporações, às suas relações com as empresas e os governos são, muitas vezes, ambíguas e emolduradas por categorias ditadas por instituições internacionais, tais como as Nações Unidas e o Banco Mundial (Spivak, 1999; Teodósio, 2008; Banerjee, 2012).

O aumento da responsabilidade das organizações (incluindo-se aqui as OSCs) para com as comunidades locais, dotando de concretude e vigor à participação popular em contextos locais, permanece como um desafio para o futuro (Escobar, 1992; Derman, 1995). As limitações de um modelo-espelho de RSE e as deficiências do racionalismo econômico baseadas no mercado precisam ser superadas. O próprio termo racionalismo econômico é problemático e precisa ser descompactado, segundo (Banerjee, 2012).

Outro ponto importante de ser destacado é que as empresas não têm a capacidade de assumir o papel dos governos no bem-estar social, simplesmente porque sua função básica é inerentemente impulsionada por necessidades econômicas. Se uma empresa, por exemplo, decidisse encerrar suas atividades em um determinado local (o que provavelmente ocorreria por razões econômicas ou demandas do mercado, e não por razões sociais ou ambientais), o que aconteceria com a comunidade local que se tornasse completamente dependente de seu bem-estar econômico, social e ambiental? A verdade é que as empresas nem sempre irão agir conforme os interesses da sociedade e que os investimentos sociais e a justiça social nunca poderão tornar-se atividades principais de uma empresa privada, a não ser que essa se constitua como uma Empresa Social. (Banerjee, 2012).

Revista de Gestão Social e Ambiental - RGSA, São Paulo, v. 9, n. 3, p. 3-23, set./dez., 2015. 
Novas fronteiras teóricas para a responsabilidade social empresarial: o papel das empresas no desenvolvimento sustentável dos territórios

A economia política que vigora nos dias de hoje influencia as estratégias corporativas, direcionando-as para criação de valor aos acionistas e ao retorno sobre o capital e não para a justiça social ou moral, segundo (Banerjee, 2012). Isso faz com que as tentativas emergentes para conceituar a responsabilidade social como "capital social" ainda fiquem aquém, ao menos que haja uma reestruturação radical da economia política repensando sobre o papel de uma empresa na sociedade (Banerjee, 2012).

Diante dessas considerações críticas sobre a Responsabilidade Social Empresarial e seus desdobramentos sobre a sustentabilidade dos territórios, propõe-se, como arcabouço teórico para pesquisas futuras, a articulação entre as abordagens sobre sustentabilidade, sobre políticas públicas ambientais, territórios e a relação entre empresas e sociedade a partir dos fundamentos da Nova Sociologia Econômica. A figura 1, expressa essas dimensões de análise que permitem a problematizam da forma como atores locais se relacionam em relação aos processos de sustentabilidade nos territórios.

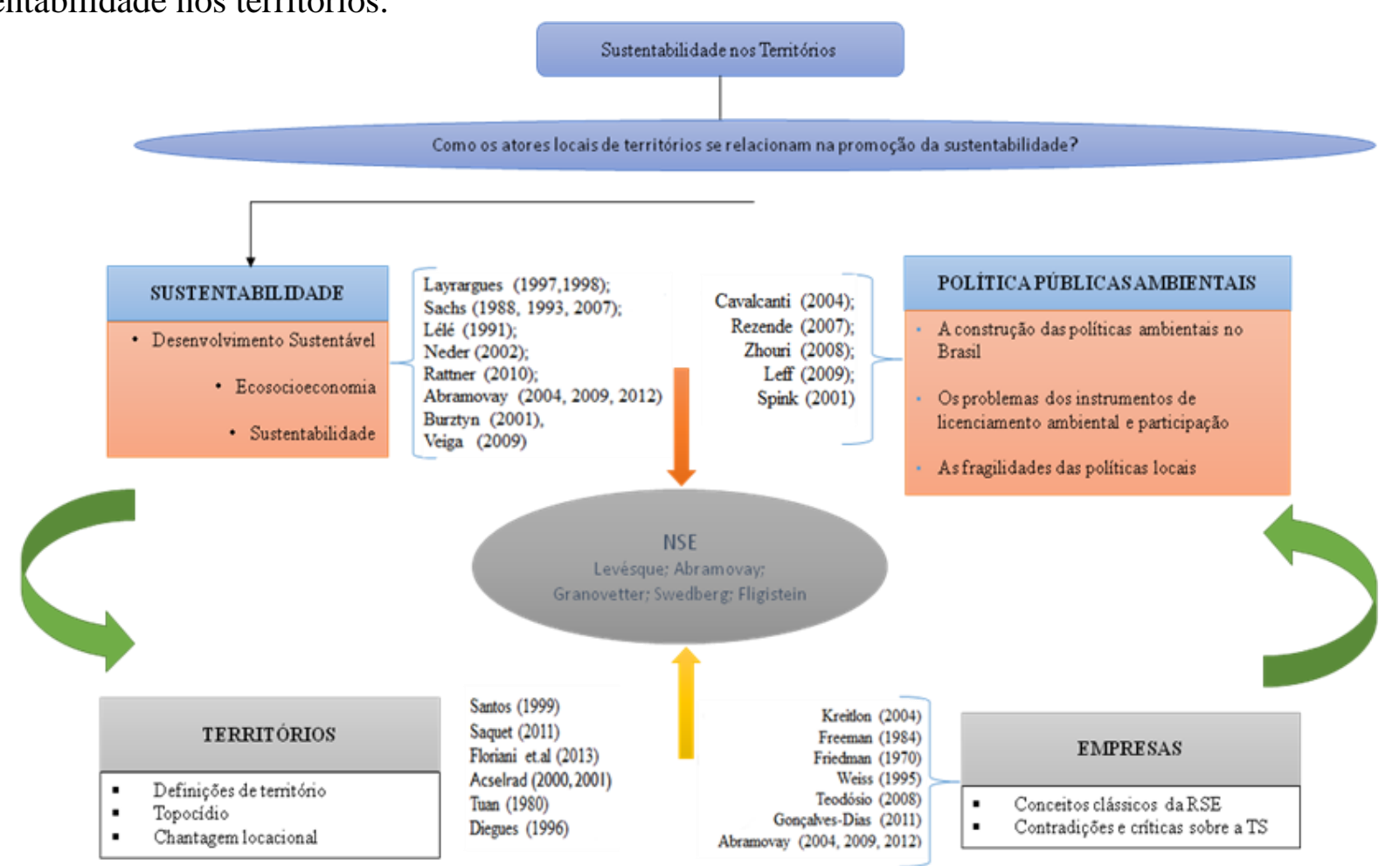

Figura 1. Modelo compreensivo sobre a RSE e sustentabilidade de territórios

Fonte: Elaborado pelos autores

Contribuições teóricas capazes de desenvolver novos olhares sobre o fenômeno da relação entre empresa e sociedade, tendo como questão de fundo a sustentabilidade dos territórios, precisam ser urgentemente desenvolvidas, de forma a superar lacunas presentes em diferentes tradições de teorização. A conjunção entre diferentes abordagens, mantendo sua coerência epistemológica, como procurou-se desenvolver no modelo teórico-compreensivo anterior, podem ser bastante úteis para um avanço consistente das investigações críticas sobre responsabilidade social empresarial e sustentabilidade, tanto no contexto brasileiro quanto internacional.

\section{CONSIDERAÇÕES FINAIS}

Torna-se fundamental analisar as dinâmicas de interação que se estabelecem entre os diferentes atores que compõem as esferas sociais, governamentais e mercadológicas, bem como suas implicações para a proteção ambiental e justiça social, procurando entender como e porque podem favorecer o DS e de que forma, onde e porque não o fazem. Se, para vários autores, a discussão sobre DS remete ao refundar da ética, calcada nos parâmetros do que Leff (2006) chama de racionalidade ambiental, para outros, exige a análise da própria noção da vida em sociedade 
estruturada em diferentes esferas, questionando a natureza constitutiva e a racionalidade dos diferentes atores, instituições e organizações que operam no âmbito governamental, dos mercados e da sociedade civil.

Uma das apropriações sobre o DS tem sido relacioná-lo à RSE, por meio da TS, que, em tese, retiraria as empresas do centro do processo de desenvolvimento e consideraria outros atores dos territórios. Essa perspectiva, porém, é marcada por uma contradição, uma vez que essas partes envolvidas seriam consideradas dentro e a partir das dinâmicas da empresa. Dessa forma, a empresa continuaria sendo o ator central no processo de DS, pois este ocorreria ao seu redor. Se pensarmos no DS como atribuição dos territórios, a RSE, na perspectiva da TS, se enfraquece.

A TS centraliza as empresas no processo de DS. Quando se pensa em territórios, as empresas não podem ser tratadas como únicas ou principais protagonistas. Territórios não possuem stakeholders, portanto, essa lógica não propõe encaminhamentos coerentes ao se projetar a sustentabilidade dos territórios. A sustentabilidade dos territórios demandaria a atuação de diferentes atores para além das empresas, com envolvimento efetivo da sociedade civil organizada, do poder público e, claro, das organizações privadas. Dessa forma, o pensar a sustentabilidade do território implica em problematizá-la a partir do próprio território como um todo.

Essa perspectiva de compreensão teórica demonstra a importância de se estabelecer um diálogo mais profundo e consistente entre as teorias de Responsabilidade Social Empresarial e as noções e os constructos teóricos desenvolvidos no âmbito do campo de conhecimento da Geografia. A dinâmica atual discute o DS como principal foco nas empresas e em seus stakeholders. As abordagens tradicionais da Teoria dos Stakeholders desconsideram o fato de que os territórios não possuem stakeholders e que o desenvolvimento sustentável dos territórios se apresenta, antes de tudo, como meta para processos de governança compartilhada, nos quais a perspectiva de stakeholders acaba oferecendo pouco para se compreender, problematizar e desenhar propostas de intervenção que, efetivamente, levam em conta não apenas os interesses empresariais, mas também os interesses, valores, compromissos e direitos e deveres dos demais atores desses mesmos territórios. Diversos atores estão inseridos em uma rede de responsabilidades para o DS dos territórios, sejam elas relativas à sociedade, ao poder público ou às empresas.

Abordar a sustentabilidade a partir da noção de território implica em considerá-lo como um todo no qual confluem diferentes atores, inclusive a empresa. Além disso, essa abordagem requer que se problematize as diferentes capacidades em termos de relações de poder dos distintos atores do território, em constante interação. No que tange à relação entre comunidades e empresa, tal análise não pode se limitar a compreender o investimento social e ambiental empresarial per si, mas o próprio compromisso de todos os atores envolvidos nesse tipo de intervenção nos territórios em transformar suas relações, inclusive com os governos, em direção a interações não baseadas apenas na assistência, mas, sobretudo, na alteração das relações de poder e governança compartilhadas de direitos e deveres ante o patrimônio social, cultural e ambiental dos territórios. Portanto, destaca-se o compromisso em alterar práticas e políticas, historicamente delineadas a partir da perspectiva da assistência, em direção à conquista do poder por parte dos grupos com menor capacidade de incidência na dinâmica de governança territorial. Bowen, Newenham-Kahindi e Herremans (2008) argumentam que o compromisso é, principalmente, uma questão de transformar a comunidade e a empresa. Segundo esses autores, o compromisso de transformação (transformational engagement, do original em inglês) é caracterizado pela aprendizagem recíproca entre empresa, comunidades e governo, gestão compartilhada de projetos e liderança da comunidade na tomada de decisões.

Portanto, o compromisso transformador requer o poder de comprometer os participantes e a criação de uma linguagem organizacional compartilhada, para que este compromisso faça sentido para a organização e, assim, tenha uma forte orientação para a realização. Isso é o que Ospina e Foldy (2010) denominam de "Liderança para a Transformação Social". Estes requisitos, transformando o compromisso de Bowen et al. (2008), sugerem, então, a disponibilidade de capital social; ou seja, de acordo Helliwell e Putnan (2004), exigiriam a existência de uma organização 
Novas fronteiras teóricas para a responsabilidade social empresarial: o papel das empresas no desenvolvimento sustentável dos territórios

social e de relações mais horizontais com base em laços de confiança. Em outras palavras, para alcançar um compromisso de transformação do território, primeiro, seria preciso construir redes organizacionais com base na confiança, que teriam a participação das empresas, porém sem tomarem para si o papel de protagonistas do desenvolvimento, ainda que possam e devam aportar um volume de recursos financeiros decisivo para isso. Assim, o compromisso de transformação dependeria da existência de redes organizacionais e confiança entre a empresa e a comunidade e não apenas das decisões estratégicas das empresas no desenho de projetos de intervenção socioambiental nos territórios.

Este artigo procurou apresentar novas possibilidades de teorização sobre a responsabilidade social empresarial e seus desdobramentos sobre os processos de desenvolvimento sustentável a partir da problematização da noção de territórios e de uma crítica às abordagens baseadas na análise de stakeholders. Considera-se que o diálogo com outros campos de conhecimento vinculados aos estudos sobre sustentabilidade, sobretudo a Geografia, podem oferecer ricas contribuições para que mais e melhores diálogos entre abordagens desenvolvidas a partir de centros de pesquisa, autores e tradições de investigação baseadas nos países desenvolvidos se estabeleçam com as teorizações empreendidas por pesquisadores e grupos de estudos dos países em desenvolvimento ou de desenvolvimento tardio. Espera-se que a perspectiva teórica aqui desenvolvida possa balizar estudos futuros, sobretudo aqueles que se baseiam na comparação entre realidades distintas de diferentes territórios, permitindo novos avanços tão necessários no conjunto de teorias sobre responsabilidade social empresarial.

\section{Referências}

Abramovay, R. (2012) Muito além da economia verde. São Paulo: Atlas.

Abramovay, R. (2009) Anticapitalismo e inserção social dos mercados. Tempo Social, revista de sociologia da USP, 21 (1), 65-87.

Abramovay, R. (2004) Entre Deus e o diabo: mercados e interação humana nas ciências sociais. Tempo Social. Revista de Sociologia da USP. 16(2), 1-19.

Acselrad, H. (2000) Sustentabilidade, espaço e tempo. In: Herculano, S. C. Meio ambiente: questões conceituais. Niterói: Ricor.

Acselrad, H., \& Bezerra, G. N. (2009) Desregulação, deslocalização e conflito ambiental. Anais: Encontros Nacionais da Anpur, 13.

Banerjee, S. B. (2012) Corporate social responsibility: the good, the bad and the ugly. Critical sociology, 34 (1), 51-79.

Barbieri, J.C. (2001) Desenvolvimento e meio ambiente. Rio de Janeiro: Vozes.

Baroni, M. (1992) Ambiguidades e deficiências do conceito de desenvolvimento sustentável. Revista de Administração de Empresas, 32(2), 14-24.

Bertrand, G. (1998) Entrevista com o professor Georges Bertrand. Geosul, Florianópolis, SC, 13(26), 144-160, jul./dez.

Bonnemaison, J. (2002) Viagem em torno do território. In: Correa, R.L., Rosendhal, Z. (Org.) Geografia cultural: um século. Rio de Janeiro: Eduerj, 3, 83-132.

Bowen, F., Newenham-Kahindi, A., Herremans, I. (2008) Engaging the community: a systematic review. London: Research Network for Business Sustainability.

Brenner, S.N. and P. Cochran. (1991) The stakeholder theory of the firm. Annual meeting of the International Association for Business and Society. 
Comissão Mundial sobre Meio Ambiente e Desenvolvimento. (1988) Nosso futuro comum. Rio de Janeiro: Editora da Fundação Getúlio Vargas.

Costa, A. C. G. (2002) Lições de aprendiz: pessoas, ideias e fatos que estão construindo uma nova história de responsabilidade social. BH: Modus Faciendi.

Dentchev, N. A., Haezendonck, E., van Balen, M. (2015) The role of governments in the business and society debate. Business \& Society, 1-18.

Diegues, A. C. S. (1996) O mito moderno da natureza intocada. São Paulo: Hucitec.

Donaldson, T. and L. E. Preston. (1995) The stakeholder theory of the corporation: concepts evidence, and implications. Academy of Management Journal, 20, 65-91.

Falkenberg, J., Brunsael, P. (2011) Corporate social responsability: a strategic advantage or a strategic necessity? Journal Busness Ethics, 99, 9-16.

Floriani, N., Ríos, F. T., Floriani, D. (2013) Territorialidades alternativas e hibridismos meridionais no mundo rural: resiliência e reprodução da sociobiodiversidade em comunidades tradicionais do Brasil e Chile. Polis, 12 (34), 73-94.

Freeman, R. E. (1984) Strategic management: stakeholder approach, Boston: Pitman.

Freeman, R. E. (1984). Strategic management: a stakeholder approach, Boston: Pitman.

Gonçalves-Dias, S. \& Teodósio, A. S. S. (2011). Perspectivas de análise do ambientalismo empresarial para além de demonizações e santificações. Revista de Gestão Social e Ambiental, 5 (2), 03-17.

Gonçalves-Dias, S., Teodósio, A. S. S., \& Barbieri, J. C. (2007) Desafios e perspectivas da sustentabilidade: caminhos e descaminhos na gestão empresarial. Encontro Nacional sobre Gestão Empresarial e Meio Ambiente, 9, 1-12.

Gond, J-P, Kang, N., Moon, J. (2011) The government of self-regulation: on the comparative dynamics of corporate social responsibility. Economy and Society, 40(4), 640-671, november.

Greenwood, M. (2007) Stakeholder engagement: beyond the myth of corporate responsibility. Journal of Business Ethics, 74, 315-327.

Habermas, J. (1984) Mudança estrutural da esfera pública. RJ Tempo Brasileiro.

Habermas, J. (1987a) Teoria de la acción comunicativa: racionalidad de la accióny racionalización social. Madrid:Taurus.

Habermas, J. (1987b). Teoria de la acción comunicativa: crítica de la razón funcionalista. Madrid: Taurus.

Helliwell, J., Putnam, R. (2004) The social context of well-being. Philosophical transactions of the royal society $B, 359,1435-1446$.

Jacobi, P. R. (2005). Educação ambiental: o desafio da construção de um pensamento crítico, complexo e reflexivo. Educação e Pesquisa, 31 (2), 233-250.

Jenkins, H., Yakvleva, N. (2006) Corporate social responsibility in the mining industry: Exploring trends in social and environmental disclosure. Journal of Cleaner Producion, 14, 271-284.

Jones, M. T. (1996) Missing the forest for the trees: a critique of the corporate social responsibility discourse. Business and Society, 35, 7-41.

Kreitlon, M. P. A. (2004) Ética nas relações entre empresas e sociedade. In: Anais do EnAnpad, 28. Curitiba: Anpad, 1-15. 
Novas fronteiras teóricas para a responsabilidade social empresarial: o papel das empresas no desenvolvimento sustentável dos territórios

Layrargues, P. P. (1997) Do ecodesenvolvimento ao desenvolvimento sustentável: Evolução de um conceito? Proposta, 25 (71), 5-10.

Layrargues, P. P. (1998) A cortina de fumaça: o discurso empresarial verde e a ideologia da racionalidade econômica. São Paulo: Annablume.

Leff, E. (2009) Complexidade, racionalidade ambiental e diálogo dos saberes. Educação $e$ Realidade, 34 (3), 17-24.

Leff, E. (2006) Racionalidade ambiental: a reapropriação social da natureza. Rio de Janeiro: Civilização Brasileira.

Lelé, S. M. (1991) Sustainable development: a critical review. World Development. 6 (19), 607-621.

Levésque, B. (2007) Contribuição da nova sociologia econômica para repensar a economia no sentido do desenvolvimento sustentável. RAE, 47 (2), 49-60.

Machado, G., Sequet, M. A. (2011) Espaço, território, paisagem: em busca de uma ligação conceitual. Revista Varia Scientia, 10(17), 119-135.

McDowell, L. (1996) A transformação da geografia cultural. In: Smith, G., Gregory, D., Martin, R., Isaack, M., Geografia humana: sociedade,espaço e ciencia social. Rio de Janeiro: Jorge Zahar, 159-188.

Massey, D. (2008) Pelo espaço: uma nova política da espacialidade. RJ: Bertrand.

Neder, R. T. (2002) Crise socioambiental: estado \& sociedade civil no Brasil, 1982-1998. Annablume.

Ospina, S., Foldy, E. (2010) Building bridges from the margins: the work of leadership in social change organizations. The Leadership Quarterly (21), 292-307.

Palier, B., Surel, Y. (2005) Les “trois i” et l'analyse de l'Etat en action. Revue Française de Sciences Politiques, 55 (1), 7-32.

Phillips, R. (2004) Some key questions about stakeholder theory. Ivey Business Journal, 1-6.

Porter, M. E., \& Kramer, M. R. (2006) The link between competitive advantage and corporate social responsibility. Harvard Business Review, 84(12), 78-92.

Santos, M. (1999a) O território e o saber local: algumas categorias de análise. Cadernos IPPUR, $8(2), 15-26$.

Santos, M. (1999b) O dinheiro e o território. GEOgraphia, 1(1), 1-7.

Sachs, I. (2007) Rumo à ecossocioeconomia: teoria e prática do desenvolvimento. Cortez.

Sachs, I. (1988) Espaços, tempos e estratégias do desenvolvimento. São Paulo: Vértice.

Sachs, I. (1993) Estratégias de transição para o século XXI. In: Para pensar o desenvolvimento sustentável. São Paulo: Brasiliense, 29-56.

Saquet, M. A. (2011) Estudos territoriais: os conceitos de território e territorialidade como orientações para a pesquisa científica. Território e fonteiras-(re) arranjos e perspectivas. Florianópolis: Insular, 33-50.

Sen, A. (2000). Desenvolvimento como liberdade. São Paulo: Companhia das Letras.

Serva, M, \& Andion, C. (2006) Teoria das organizações e a nova sociologia econômica: um diálogo interdisciplinar. RAE, 46 (2), 10-21.

Sheehy, B.(2015) Defining CSR: problems and solutions. Journal of Business Ethics, 131, 625-648. 
Silveira, A.M., Yoshinaga, C., Borba, P. (2004) Crítica a Teoria dos Stakeholders como funçãoobjetivo corporativa. Caderno de Pesquisas em Administração, 12(1), 33-42.

Spivak, G.C. (1999).A critique of postcolonial reason: toward a history of the vanishing present. Harvard University Press: Cambridge.

Swedberg, R. (2004) Sociologia econômica: hoje e amanhã. Tempo social, 16 (2), 7-34.

Teodósio, A. S. S. (2008). Parcerias tri-setoriais na esfera pública: perspectivas, impasses $e$ armadilhas para a modernização da gestão social no Brasil. Tese de doutorado, EAESP, Fundação Getúlio Vargas, São Paulo, Brasil.

Teodósio, A.S.S., Carvalho Neto, A.M. (2003) Público ou privado? Investimentos sócio-ambientais de empresas. In: Anais do Engema, 7. SP: FGV \& USP, 1-13.

Tuan, Y.F. (1980). Topofilia: um estudo da percepção, atitudes e valores do meio ambiente. São Paulo: Difel.

Tullberg, J. (2005) Reflections upon the responsive approach to corporate social responsibility. Business ethics: a european review, 14(3), 261-276.

Vasconcellos, I. F. F. G., Alves, M. A., \& Pesqueux, Y. (2012) Responsabilidade social corporativa e desenvolvimento sustentável: olhares habermasianos. Revista de Administração de Empresas, São Paulo, 52 (2), 148-152.

Veiga,J.E.D.(2009).Mundo em transe do aquecimento global ao ecodesenvolvimento. Armazém Ipê.

Weiss, A. R. (1995) Cracks in the foundation of stakeholder theory. Eletronic Journal of Radical Organization Theory, 1(1).

Windsor, D. (2001) Corporate citizenship: evolution and interpretation. J. Andriof and M. McIntosh (eds). Perspectives on corporate citizenship, 39-52.

Zhouri, A., Laschefski, K. \& Pereira, D. (2005). (orgs.) A insustentável leveza da política ambiental: desenvolvimento e conflitos socioambientais. BH: Autêntica

Recebido em: 22/05/2015

Publicado em: 21/12/2015 